Scottish Museum, Edinburgh, with Dr. Hanna T. Rose, of the Brooklyn Museum, New York, as associate director. Senior officers will deal with individual subjects as follows: Dr. Torsten Althin (Tekniska Museet, Stockholm), science museums; Dr. J. Wijenbeek (Municipal Museum, The Hague), art museums ; and Dr. F. T. de Souza (Ministry of Education, Rio de Janeiro), educational organization. Forty-five participants representing their respective countries in the United Nations will attend the seminar, together with fifteen expert observers, representing interested parallel or kindred organizations. There will be opportunities for inspecting museum and educational projects as far afield as Washington, D.C. The topics for discussion will include the following: subjects of education in various countries suitable for museum treatment, and the extension of school and college curricula to utilize museum resources for the training of museum and educational staffs for the work under consideration; the varied techniques required for different mental ages ; contributions to the development of the handicapped; the initiation of fundamental education in underdeveloped countries; and the employment of the latest scientific inventions in the more advanced centres.

\section{Lectures on Nuclear Reactors}

A COURSE of thirty lectures will be given in the City and Guilds College, University of London, during the 1952-53 session by members of the Atomic Energy Research Establishment (Ministry of Supply), Harwell. The first group of twelve lectures will be concerned with slow-neutron natural uranium reactors, concluding with a detailed description of the large pile at Harwell (BEPO). Another group of six lectures will deal with particular aspects of reactors of various types. Information will be given on the various possible systems, and the problems involved in metallurgy, chemistry, engineering, heat transfer and physies, will be discussed. One lecture on health physics will be included. A group of three specialized courses will include five lectures for mathematicians on more advanced slow- and fastneutron theory; five lectures for engineers on heat transfer and reactor design; and a lecture for physicists on the experimental use of a reactor, followed by the opportunity to take part in experiments involving neutron diffusion and the measurement of a neutron flux. At the end of the course it is hoped to arrange a visit to inspect the Harwell piles and give an opportunity for informal discussion with the various lecturers. All the lectures are free to students of the City and Guilds College and London intercollegiate students; for others a fee of ten guineas, to be paid to the City and Guilds College, London, S.W.7, will be charged for the whole course, with reductions for those who wish to attend only a selected part.

\section{British Institution of Radio Engineers : Awards for 1951}

THE British Institution of Radio Engineers has announced the following awards for 1951: Clerk Maxwell Premium (for the most outstanding paper published in the Institution's Journal during the year), to Dr. H. Paul Williams (formerly of A. C. Cossor, Ltd., and now with Fairey Aviation Co.) for his paper on "Subterranean Communication by Electric Waves"; Heinrich Hertz Premium, to R. E. Spencer (E.M.I. Engineering Development, Ltd.) for his paper on "The Detection of Pulse Signals near the Noise Threshold"; Louis Sterling Premium, to Emlyn Jones (Mullard Research Laboratory) for his paper on "Scanning and E.H.T. Circuits for WideAngle Picture Tubes" ; Leslie McMichael Premium, to R. G. Kitchenn (formerly of the Local Lines and Wire Broadcasting Branch of the Engineer-in-Chief's Office, General Post Office) for his paper on "An 8-Channel Transmitter for an Experimental Carrier Wire-Broadcasting System" ; Brabazon Premium (for the most outstanding contribution to the Institution's Proceedings on radio or electronic aids to aircraft safety), to G. E. Roberts (Decca Navigator Co., Ltd.) for his paper on "The Design and Development of the Decca Flight Log" ; Marconi Premium, to E. G. Rowe (Brimar Valve Division, Standard Telephones and Cables, Ltd.) for his paper on "The Technique of Trustworthy Valves"; President's Prize (awarded to the most successful candidate in the Graduateship examination) and the Electronic Measurements Prize (awarded to the most outstanding candidate in Part IV, electronic measurements, of the Graduateship examination), to G. R. Beswick (Birmetals, Ltd., Quinton, Birmingham); Mountbatten Medal (awarded to the most successful candidate who passed the Graduateship examination while serving in the Armed Forces), to C. J. White (B.B.C., Daventry, and formerly of the R.A.F.).

\section{Announcements}

Mr. WIILIAM E. Miller has been nominated president-elect of the British Institution of Radio Engineers for 1952-53. Mr. Miller has been a member of the Institution for twenty years and was elected a vice-president in 1948, having previously been chairman of the General Council. He was one of the original signatories to the incorporation of the Institution in 1932.

THE first of the Radio Industry Council's premiums of 25 guineas for technical writing, to be awarded to authors of technical articles deserving to be commended by the industry, has been won by Mr. J. R. Acton, of the Ericsson Research Laboratories, Nottingham, for his article on "The Single-Pulse Dekatron", published in the February issue of Electronic Engineering. The dekatron is a new type of gas-filled cold-cathode ray tube now being developed for use in scalers and computors.

Mr. T. E. Goldup, a director of Mullard, Ltd., has been appointed chairman of the Board of Governors of the Ministry of Supply School of Electronics, Malvern, in succession to Prof. Willis Jackson, professor of electrical engineering, Imperial College of Science and Technology, London. Mr. Goldup, who has had a wide experience of technical education in the electronics field, has been with the Mullard organization for more than twenty-nine years, and was formerly a member of the research staff of the Signal School, Portsmouth.

Erratum. In the communication entitled "Some Electrical Differences between Healthy and Virusinfected Potato Tubers", by C. G. Greenham et at., which was published in Nature of June 7, p. 973, it is regretted that the top portion of the illustration is incorrect and should be as follows:

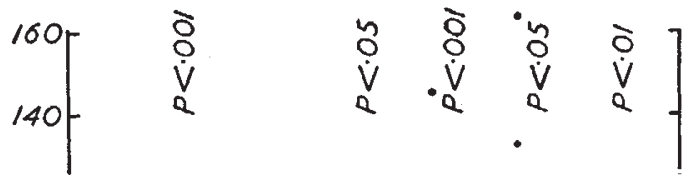

